Research Article

\title{
Armenia and the South Caucasus: A New Security Environment
}

\section{Anthony R. Branch}

New York University, Graduate School of Arts and Sciences, https://gsas.nyu.edu/

Caucasus Research Resource Center - Armenia Foundation, http://www.crrc.am/

\begin{abstract}
This article seeks to examine through a realist international relations' lens the geopolitics and the security environment of the South Caucasus, and specifically the security challenges Armenia will face over the next five years. As the South Caucasus is cemented by collective security agreements and the stagnant conflict over Nagorno-Karabakh, the regional dynamic shifts incrementally. Significant historical events, such as the Baku-Tbilisi-Ceyhan pipeline, the April 2016 Karabakh flare-up, and the completion of the Trans-Anatolian Pipeline provide the foundation for a forward leaning analysis. This article addresses three questions. First, considering the changing international order, what is the current security environment in the South Caucasus? Second, what are the geopolitical concerns in the South Caucasus? Third, what are the specific national security challenges for Armenia? It reveals that the South Caucasus security environment is energy focused, changes in the Nagorno-Karabakh conflict are contingent upon energy geopolitics and Russia, and that Russia will continue to hinder Armenia's growth and independence, thus challenging Armenia's security, whilst at the same time providing for Armenia's security.
\end{abstract}

Keywords: Energy geopolitics, Russia, Nagorno-Karabakh, Azerbaijan, energy dependence, collective security. 


\section{Purpose, Scope and Key Assumptions}

The purpose of this article is to examine the geopolitics and the security environment of the South Caucasus and, more specifically, the security challenges Armenia is expected to face over the next five years.

The South Caucasus geopolitics and Armenia's security challenges in midterm are analyzed through a realist lens. It is appropriate to look five years ahead, because the South Caucasus geopolitical environment shifts incrementally. In addition, a significant governmental change has occurred in Armenia, and the international order is also changing.

This article will examine paradigm shifts, anticipated with the completion of the Trans-Anatolian Pipeline (TANAP), and noteworthy events, such as the April 2016 Karabakh war. By referring to these moments of significance and drawing upon academic literature, we will establish a foundational background for analysis. This analysis utilizes public information and resources that, in combination, provide for a comprehensive and open framework. This article will not discuss economics beyond political-economic implications, internal security concerns of Armenia or any other state, the legitimacy of the Republic of Nagorno-Karabakh (or Artsakh), corruption, terrorism, or drug or human trafficking. In addition, this paper will not attempt to make predictions or policy prescriptions.

This article will attempt to answer three questions: First, considering the changing international order, what is the current security environment in the South Caucasus? Second, what are the geopolitical concerns in the South Caucasus? Third, what are the specific national security challenges for Armenia?

A number of assumptions have made at the start of the underlying study:

- It is highly probable that the South Caucasus security environment is energy focused;

- There is a roughly even chance that Azerbaijan will exhaust its oil resources in 24 years;

- Roughly even is also the chance that Armenia will be able to attain funding and construct a new nuclear facility within five years;

- Roughly even are the odds that the North-South Energy Corridor (NSEC) will be constructed and operational in the next five years;

- The Nagorno-Karabakh conflict status will almost certainly remain unchanged;

- It is likely that Azerbaijan will hold the regional geopolitical strategic advantage for the next five years;

- The chance that Turkish-Armenian rapprochement will occur in the next five years is remote;

- It is almost certain that Russia will continue to hinder Armenia's independence. 


\section{Conceptual Framework}

The Caucasus has been a historically significant region of the world, connecting Central Asia, Europe, the Middle East, and Russia together. After the dissolution of the Soviet Union in 1991, the independence of Commonwealth states and governmental stability became the foremost issue. ${ }^{1}$ Following the establishment of legitimate regimes, the international and regional effort to cultivate and develop the natural resources of the region took place; and specifically of Caspian Sea oil and natural gas. ${ }^{2}$ After 2001, the security environment changed to incorporate the U.S. War on Terror, and the Caucasus cooperation in the international coalition. ${ }^{3}$ Without much adjustment since 2001, by 2018 the security environment has altered once more, as well as the international order. ${ }^{4}$ Hence, a contemporary analysis of the environment must be examined. This issue is particularly timely due to the unprecedented change in government in Armenia. ${ }^{5} \mathrm{I}$ intend to take on this gap in the academic literature by reviewing the historical progression of the various security environments, contemporary concerns and challenges, thus providing a forward leaning analysis to address current issues.

\section{Literature Review}

In this review of the literature, the focus is on the evolution of the security environment, the security concerns in the Caucasus region, and the specific security issues in Armenia.

Garnik S. Asatryan in his work, "Armenia and Security Issues in the South Caucasus" gives a baseline of Armenian national security challenges and concerns in 2002. ${ }^{6}$ He focuses on the instability and insecurity of the Caucasus through three lenses: strategic, ethno-political, and cultural, with the last two being most significant. Asatryan identifies several strategic challenges: global stakeholders jockeying for position in the Caucasus, paralyzed economic systems, dependence on international financial structures, struggles to meet requirements of Euro-

1 Richard Giragosian, "Shifting Security in the South Caucasus," Connections: The Quarterly Journal 6, no. 3 (Fall 2007): 100-106, quote on p. 101, https://doi.org/ 10.11610/Connections.06.3.06.

2 Giragosian, "Shifting Security in the South Caucasus."

3 Giragosian, "Shifting Security in the South Caucasus."

4 Rebecca Friedman Lissner and Mira Rapp-Hooper, "The Day after Trump: American Strategy for a New International Order," The Washington Quarterly 41, no. 1 (Spring 2018): 7-25, https://twq.elliott.gwu.edu/sites/g/files/zaxdzs2121/f/downloads/ TWQ_Spring2018_LissnerRappHooper_0.pdf.

5 Alec Luhn, "Armenia Opposition Leader Nikol Pashinyan Elected PM by Parliament," The Telegraph, May 8, 2018, https://www.telegraph.co.uk/news/2018/05/08/ armenia-opposition-leader-nikol-pashinyan-elected-pm-parliament/.

6 Garnik S. Asatryan, "Armenia and Security Issues in the South Caucasus," Connections: The Quarterly Journal 1, no. 3 (2002): 21-30, https://doi.org/10.11610/Connections. 01.3.04. 
pean institutions, emerging conflicts, and corruptible policy makers. Asatryan views the ethno-nationalist policies of Turkey and the autonomous Kurdish region as a threat to Caucasus stability, and to Armenia more specifically. He argues that if the Caucasus states can form a regional Caucasian identity, then regional unity can stabilize the Caucasus. In regards to Armenia, Asatryan discusses the various dynamics. First, the political leaders are a small group that has altered policies for their personal benefit, rather than in pursuit of the national interests. This may now be changing since Serzh Sarkisian has resigned and Nikol Pashinyan took office. Second is the continuous economic decline and political tension related to the Karabakh war. Third, unlike its neighboring states, Armenia has an ethnically homogenous population and does not suffer from the effects of major political separatist movements. ${ }^{7}$

In 2004, Hayk Kotanjian, an Armenian military diplomat and head of both the Institute for National Strategic Studies and the Armenian National Defense Research University, published "Armenian Security and U.S. Foreign Policy in the South Caucasus." In that article he argued that although Armenia and the Caucasus have been overlooked, the United States should reconsider its interest in Armenia. He explains that although Armenia is a signatory to the Collective Security Organization (CSO) of the Newly Independent States, Armenia has participated in NATO's Partnership for Peace (PfP) program since 1994. Kotanjian argues for Armenia's Western stance as a member of the European Council, and its membership in the Organization for Security and Cooperation in Europe (OSCE). He argues that as a result of this unique balance between Russian and American collective security agreements, Armenia provides an important and strategic opportunity for dialogue between the United States and Russia. ${ }^{8}$

In the aforementioned article by Richard Giragosian, the author describes the history of the various security environments from the independence of the Caucasus states after 1991 to the post-2001 environment. Giragosian asserts that the Caucasus region during the 1990s was developed primarily for the harvesting of Caspian Sea energy reserves of oil and natural gas. After the September 11, 2001 attacks on the United States, the War on Terror was launched. The Caucasus states became key partners in this new War on Terror, as the United States and Russia, together, utilized the land, airspace, and overall cooperation of the Caucasus states to assist in Afghanistan. Giragosian observes in 2007 that Russian military posture has become increasingly anti-Western. By 2018, this trend has been strengthened and may affect Armenia's relationship with Europeans and the Americans. He also observes that Armenia is the only Caucasus state that remains committed to a strong alliance with Russia, and this remains true by this day. In addition, he observes the political and economic friendliness between Armenia and Iran as a 'bridge' from Moscow to Tehran. Russian and Iranian part-

Asatryan, "Armenia and Security Issues in the South Caucasus."

8 Hayk Kotanjian, "Armenian Security and U.S. Foreign Policy in the South Caucasus," Connections: The Quarterly Journal 3, no. 2 (Summer 2004): 15-32, https://doi.org/ 10.11610/Connections.03.2.03. 
nership in Syria has only increased this political friendliness. Giragosian's most significant point is "Legitimacy is the key determinant of durable security and stability, while the strategic reality of the region is defined less by geopolitics, and more by local politics and economics." 9

Thomas de Waal, a prominent scholar of the Caucasus region, authored the chapter "The South Caucasus in 2020" of the 2011 book Russia in 2020: Scenarios for the Future. ${ }^{10}$ It provides an analysis on the security challenges facing the South Caucasus. De Waal focuses on the cultural aspect of the South Caucasus as a lens for his analysis. He states that the younger generations, even in Armenia, choose to acquire a more globalized cultural diet through national and international media, rather than from Russian media. In addition, all three Caucasus states are less dependent on Russia than they ever were, predicting that the trend will continue. De Waal argues that the Caucasian labor integration into Russia provides a healthy interdependence and economic benefit between the Caucasus and Russia. However, it drains the Caucasus of some of its most useful labor pool. De Waal then gives a country breakdown, asserting that Azerbaijan is set to have a major crisis by 2020 , citing inequality and severe corruption from the oil and gas wealth. In 2018, Ilham Aliyev has been re-elected again, possibly increasing the chances for a crisis by 2020 . His assessment of Armenia is that it is politically fragile and has the opportunity to expand relations westward if a rapprochement with Turkey can be achieved, and from a stronger relationship with the European Union. ${ }^{11}$

\section{External Threats}

\section{The Nagorno-Karabakh Conflict and Azerbaijan}

In 1987, the Nagorno-Karabakh dispute escalated into violence between Armenia and Azerbaijan, while still being part of the Soviet Union. ${ }^{12}$ NagornoKarabakh is a section of mountainous territory that was awarded to Azerbaijan from the Soviet Union. Nagorno-Karabakh holds historical and religious significance to Armenia, as it is a historical part of Armenia and has predominantly Armenian population. From 1987-1991 violent pogroms and military force was exercised on both sides ${ }^{13}$; from 1992-1994 full scale war erupted. Amid consid-

9 Giragosian, "Shifting Security in the South Caucasus," 106.

10 Thomas de Waal, "The South Caucasus in 2020," in Russia in 2020: Scenarios for the Future, ed. Maria Lipman and Nikolay Petrov (Washington, D.C.: Carnegie Endowment for International Peace, December 2011), 109-122.

11 Maria Lipman and Nikolay Petrov, eds., Russia in 2020: Scenarios for the Future (Washington, D.C.: Carnegie Endowment for International Peace, December 2011).

12 Stuart J. Kaufman, Modern Hatreds: The Symbolic Politics of Ethnic War (Ithaca, NY: Cornell University Press, May 31, 2001), 62, 49.

13 Kaufman, Modern Hatreds, 49-50. 
erable international pressure and 20,000 deaths, the violence was stopped by a ceasefire agreement brokered by Russia in $1994 .{ }^{14}$

The 1994 ceasefire is the only tangible diplomatic achievement towards the resolution of this conflict; all other peace talks have failed. ${ }^{15}$ In April of 2016, in what became known as the Four Day War, military violence between Azerbaijan and Armenia erupted, ${ }^{16}$ killing at least 200 people. ${ }^{17}$ In this war, Armenia lost some controlled territory ${ }^{18}$ in a clear display of Azerbaijan's advancement in its military capability since 1994. Although the ceasefire agreement is regularly broken, ${ }^{19,20}$ there has not been any large-scale violence since 1994 , with the exception of April 2016.

The de facto government or "Republic of Nagorno-Karabakh" ${ }^{21}$ uses joint Armenian and "Artsakh" military forces to defend the line of contact and the surrounding controlled territories. Armenia has reason to be concerned with the integrity of its defense of Nagorno-Karabakh, since Azerbaijan proved its increased military aptitude in the April 2016 War. In addition, Azerbaijani troops are trained by Turkish forces in both Azerbaijan proper and in the Nakhchivan exclave that borders Armenia, Iran, and Turkey. ${ }^{22}$ While Azerbaijan has continued to purchase Russian arms, ${ }^{23}$ it started buying arms, including air-to-surface missiles, from Turkey. ${ }^{24}$ Regardless, Armenian and Karabakh forces should be

14 Kaufman, Modern Hatreds, 73-74.

15 Ohannes Geukjian, Negotiating Armenian-Azerbaijani Peace: Opportunities, Obstacles, Prospects (Burlington, VT: Ashgate Publishing Company, 2014).

16 "Nagorno-Karabakh Conflict," Council on Foreign Relations, October 2017, https://www.cfr.org/interactives/global-conflict-tracker\#!/conflict/nagornokarabakh-conflict.

17 "Nagorno-Karabakh's Gathering War Clouds," Europe Report no. ${ }^{\circ} 244$ (Brussels: International Crisis Group, June 1, 2017), https://d2071andvip0wj.cloudfront.net/ 244-nagorno-karabakhs-gathering-war-clouds.pdf.

18 “Nagorno-Karabakh's Gathering War Clouds," 2.

19 "Armenian Ceasefire Violation: Azerbaijan's Serviceman Killed," Trend, January 19, 2018, https://en.trend.az/azerbaijan/karabakh/2849943.html.

20 "Nagorno-Karabakh Reports 250 Azerbaijani Ceasefire Violations," Tert, March 3, 2018, http://www.tert.am/en/news/2018/03/03/karabakh/2629054.

21 It should be noted that in 2016, the de facto government of Nagorno-Karabakh, or "The Republic of Nagorno-Karabakh," changed its name to the "Republic of Artsakh"; it is commonly referred to as "Artsakh" in Armenia.

22 Ilgar Gurbanov, "Interaction with Turkish Air Force Boosts Azerbaijan's Air-Combat Capability," Eurasia Daily Monitor 14, no. 137 (The Jamestown Foundation, October 26, 2017), https://jamestown.org/program/interaction-turkish-air-forces-boostsazerbaijans-air-combat-capability/.

23 Yulia Zhuchkova, "Armenia's Hands Are Tied Regarding Russian Arms Sales to Azerbaijan," The Jamestown Foundation, July 26, 2017, https://jamestown.org/armeniashands-are-tied-regarding-russian-arms-sales-to-azerbaijan/.

24 “Azerbaijan Has Bought SOM Missile from Turkey," Azeri Defence, June 26, 2018, http://en.azeridefence.com/azerbaijan-has-bought-som-missile-from-turkey/. 
able to retain their tactical ground superiority because of their elevated territorial advantage.

As Azerbaijan's oil reserves begin to dwindle over the next 24 years, ${ }^{25}$ it will be challenging for the Aliyev regime to sufficiently diversify the economy in preparation for the presumed economic shock. If the economic crisis hits, the domestic political atmosphere will become tumultuous, unstable, and uncertain for the survival of the Aliyev regime. Thus, the Nagorno-Karabakh conflict is likely to be its foreign adventure to distract the public from domestic issues by providing a scapegoat to keep the regime alive.

Beyond the Nagorno-Karabakh conflict, Azerbaijan's increasing pipeline projects tilt the geopolitical balance in favor of Azerbaijan. First, by investing in multi-national energy projects, most notably with Georgia and Turkey, Azerbaijan exports its Caspian energy to Europe, making it a critical alternative source, instead of Europe's continuous reliance on Russia or Middle Eastern states. ${ }^{26}$ Second, Azerbaijan profits from the sale of its energy. Third, by including Georgia and Turkey in these projects, it creates an inherent multi-beneficiary outcome, such as increased diplomatic relations, economic benefits (shared revenue and job creation), and less dependence on Russian energy. Fourth, besides TANAP, the main investor in all of Azerbaijan's energy projects is $\mathrm{BP},{ }^{27}$ a UK-based petroleum corporation, thus enhancing British and western affinity for the energy-rich state.

With this Azerbaijani geopolitical advantage, Armenia incurs losses in three main ways. First, Armenia loses influence in Georgian-Armenian relations as Georgia will find Azerbaijan a much more profitable and beneficial partner. As Georgia aims to decrease its dependence on Russia, Azerbaijani pipeline projects provide employment, financial gain, and energy. Second, the three of Armenia's four neighbors all become richer from these energy partnerships, thus increasing the financial disparity between Armenia and its neighbors. Third, Azerbaijan makes substantial gains with European countries as a necessary alternative for energy, especially as Western and Russian relations continue to worsen, ${ }^{28}$ thus giving more hard value to Azerbaijan over Armenia, regardless of Armenia's more European aligned governance and values. This could also undercut support or neutrality for Armenia in the Nagorno-Karabakh conflict.

25 "BP Statistical Review of World Energy: 67 th Edition," $B P$, June 2018, 12, 14, www.bp.com/content/dam/bp/en/corporate/pdf/energy-economics/statisticalreview/bp-stats-review-2018-full-report.pdf.

26 Armen Manvelyan, Energy Security and Geopolitical Challenges in the CaucasusCaspian Region (Yerevan, Armenia: Yerevan State University, 2015), 194, 198.

27 Manvelyan, Energy Security and Geopolitical Challenges, 193.

28 Gardiner Harris, "U.S. To Issue New Sanctions on Russia Over Skripals' Poisoning," The New York Times, August 8, 2018, https://nyti.ms/2OUvbvo. 


\section{Turkey}

While Turkish and Armenian relations have never been good, ${ }^{29}$ the opportunity for rapprochement following Armenia's independence from the USSR was negated as Turkey backed Azerbaijan in the outbreak of the Nagorno-Karabakh conflict. Although Turkey recognized Armenia as an independent state in 1991, it closed its border with Armenia in 1993 in support of Azerbaijan over the Nagorno-Karabakh war. ${ }^{30}$ Between 2008 and 2009, Turkey made attempts to normalize relations with Armenia, but the initiative collapsed as a consequence of strong pressure from Azerbaijan, who succeeded to make progress in normalizing Armenian-Turkish relations contingent upon its settlement proposals for the Nagorno-Karabakh conflict. ${ }^{31}$ In the immediate future, the normalization of relations between Yerevan and Ankara does not seem possible. Armenians have increased mistrust for Turkey, while domestic support for rapprochement has declined.

Although Turkish-Armenian relations are not improving, it is highly unlikely that Turkish troops will cross the border and attack Armenia. First, Armenia is a signatory to the Collective Security Treaty Organization (CSTO), with Russia as its security guarantor. Second, the United States and other NATO members are certainly uninterested in being drawn into a petty regional conflict, resulting in a fight with Russia. Third, Armenia is no longer a high priority of Turkish foreign policy concerns. With the Syria conflict on Turkey's borders, internal unrest and divisions amongst the population, concerns with Greek relations over Mediterranean islands and Cyprus, as well as its souring relations with the United States, Turkey is not immediately concerned with rapprochement or attacking Armenia.

In 2010, Turkey and Azerbaijan signed a Strategic Partnership agreement, ${ }^{32}$ further impeding the opportunity to establish diplomatic relations with Armenia. This military partnership with Azerbaijan has been enhanced in recent years by increasing the frequency and capacity of joint-military exercises in both mainland Azerbaijan and in the Nakhchivan exclave. ${ }^{33}$ While Azerbaijan sees the strategic partnership as a counter balance to Russian-Armenian military partnership,

29 Fiona Hill, Kemal Kirişci, and Andrew Moffatt, "Armenia and Turkey: From Normalization to Reconciliation," Brookings Institution, February 24, 2015, https://www.brookings.edu/articles/armenia-and-turkey-from-normalization-toreconciliation/.

30 Audrey L. Altstadt and Rajan Menon, "Unfrozen Conflict in Nagorno-Karabakh: Why Violence Persists," Foreign Affairs, April 12, 2016, https://www.foreignaffairs.com/ articles/armenia/2016-04-12/unfrozen-conflict-nagorno-karabakh.

31 F. Stephen Larrabee and Alireza Nader, "Central Asia and the Caucasus," in TurkishIranian Relations in a Changing Middle East (Santa Monica, CA: RAND Corporation, 2013), 19-20, https://www.rand.org/pubs/research_reports/RR258.html.

32 Zaur Shiriyev, Eka Tkeshelashvili, and Mitat Celikpala. "Institutionalizing a Trilateral Strategic Partnership: Azerbaijan, Georgia, Turkey," Policy Paper (Konrad Adenauer Stiftung, 2016), 12, http://www.kas.de/wf/doc/kas_43884-1522-1-30.pdf.

33 Shiriyev, Tkeshelashvili, and Celikpala, "Institutionalizing a Trilateral Strategic Partnership," 14. 
Turkey views it as a guarantee for the flow of energy resources from the Caspian Sea basin. ${ }^{34}$

As observed in history, the geographic position of Turkey was one of the most important geostrategic locations in the world, and it still is. Today, Turkey uses its geostrategic position to deliver energy from the Middle East and the Caucasus to Europe. As Turkey is not as rich as its neighbors in energy, it has positioned itself as the main facilitator in the transit of oil and natural gas, ${ }^{35}$ with the BakuTbilisi-Ceyhan Pipeline for oil and the TANAP for natural gas being of key importance.

\section{Energy Geopolitics is the New Security Environment}

Energy geopolitics shapes the new security environment of the South Caucasus. Although the South Caucasus has always had an energy focus, the completion of the TANAP ${ }^{36}$ on June 12, 2018 solidified the full transition to an energy dominant security environment.

Besides Russia, Azerbaijan is the most energy-rich state in the Caucasus. ${ }^{37}$ As described above, Azerbaijan operates and benefits from its multi-national energy projects in a multifaceted manner, challenging the balance of power in the South Caucasus. Despite this, Russia is and will continue to be the most dominant energy and military player in the Caucasus. Russia has enormous reserves of oil and natural gas in comparison to its Caucasus counterpart. While Russia's official position in the Caucasus is neutrality amongst all the states, it implicitly (and sometimes explicitly) is most aligned with the Armenian position. Likewise, Armenia is most aligned with the position of Russia, and is the only country in the Caucasus to be in that position. ${ }^{38}$

Due to the Nagorno-Karabakh conflict, Armenia has been excluded from Azerbaijani energy deals with Georgia and Turkey. Therefore, it was forced to seek opportunities to increase its own energy security. ${ }^{39}$ This gave Russia the invitation to invest in Armenia, henceforth dominating and controlling its energy sector. Armenia's partnership with Russia not only allowed for Armenia's energy sector to become secure, but for Armenia to gain a surplus of energy that it could

34 Larrabee and Nader, "Central Asia and the Caucasus," 19.

"BP Statistical Review of World Energy: 67 ${ }^{\text {th }}$ Edition," 22-23.

36 "Reference Documents," TANAP Natural Gas Transmission Company, https://www.tanap.com/reference-documents/.

37 “BP Statistical Review of World Energy: 67 $7^{\text {th }}$ Edition," 12, 26.

38 Collective Security Treaty Organization, http://www.odkb.gov.ru/start/index_a engl.htm.

39 Armen Manvelyan, "The Implications for Eurasian Economic Union and South Caucasus Energy Policy" (Yerevan: Institute of Oriental Studies, National Academy of Science, April 2018), available at https://www.researchgate.net/publication/324532 430_armen_manvelyan_the_implications_for_eurasian_economic_union_south_cau casus_energy_policy. 
resell on regional markets. Consequently, Armenia joined the Eurasian Economic Union (EEU).

While these Azerbaijani energy projects have played a stabilizing role in the regional security environment, they also made peace and stability dependent on international oil prices. ${ }^{40}$ Hence, when global oil prices declined significantly after $2014,{ }^{41}$ the diminishing role of Azerbaijan in the region and the lifting of oil sanctions on Iran both contributed to regional instability. The result of such instability and increased confrontation was witnessed during the April $2016 \mathrm{Na}$ gorno-Karabakh war. This shift between 2014 and 2016 allowed for an opening between Russia and Iran to develop the planned North-South Energy Corridor (NSEC) initiative that would include Armenia and Georgia as transit states for Russian and Iranian energy, resulting in a shift of the geopolitical balance of power. ${ }^{42}$ Specifically, it would create a counterbalance-financially and diplomatically (Georgia) - to Azerbaijani-Turkish energy cooperation.

In addition to the effect of lowering global oil prices on Azerbaijan's regional positioning, Russia's fossil fuel reserves are much larger than those of Azerbaijan, resulting in a more sustainable situation. Russia's oil reserves are 106.2 billion barrels, and its natural gas reserves are 35 trillion cubic meters, in contrast to Azerbaijan's 7 billion barrels of oil and 1.3 trillion cubic meters of gas. ${ }^{43}$ It should be clear that Azerbaijan's projects are dwarfed in comparison to Russia's global projects, but this is only a regional analysis.

Azerbaijan views its dependence on its oil and gas as one of its own critical internal threats. ${ }^{44}$ At its current rate of production, and barring any significant further discoveries, Azerbaijan's oil resources will be exhausted in approximately 24 years. ${ }^{45}$ While according to current estimates Azerbaijan's natural gas will last much longer, it is far less lucrative. This means that Azerbaijan will be forced to not only diversify its economy to brace for the economic hardship, but it will also need to find a method of securing its value to its regional and European partners in that same period of time. Azerbaijan is well aware of the importance of its regional strategic partnerships with Georgia and Turkey, as Aliyev has declared as his national security priority to maintain the "... trilateral strategic partnership and deepening cooperation between Azerbaijan, Georgia and Turkey." 46 Should Azerbaijan not supplement its oil for another commodity (resources or services), its national security and stability will be exposed to high risk.

40 Manvelyan, "The Implications for Eurasian Economic Union," 21.

41 "Crude Oil Prices Down Sharply in Fourth Quarter of 2014," U.S. Energy Information Administration, January 6, 2015, https://www.eia.gov/todayinenergy/detail.php?id= 19451.

42 Manvelyan, "The Implications for Eurasian Economic Union," 22.

43 "BP Statistical Review of World Energy: 67 $7^{\text {th }}$ Edition," 12, 26.

44 Hayk Kocharyan. "Regional Security Dynamics: Azerbaijan," 76. In Analytical Bulletin: Center for Civilization and Cultural Studies (2017).

45 "BP Statistical Review of World Energy: 67 ${ }^{\text {th }}$ Edition," 12, 14.

46 Kocharyan, "Regional Security Dynamics: Azerbaijan," 86. 
In the current state of the South Caucasus-a set of countries locked by security guarantees (with the exception of Georgia) - the balance of power can be meaningfully shifted only through energy geopolitics. In this respect, Armenia needs to build a new nuclear energy power plant. The current plant, built in the 1970s as part of the USSR, is outdated. ${ }^{47}$ The EU deemed it unacceptable and insisted that it is decommissioned by 2016. Russia then restored critical components to extend the life of the plant by 10 years. ${ }^{48}$ Thus, by 2026 Armenia must have a new and operational nuclear power plant, as it provides $40 \%$ of the electricity to Armenia. The only hindrance to its construction is the lack of funding. The project will require five billion USD for construction; currently, Russia is the only donor with an offer of 4.5 billion USD. ${ }^{49}$

A new power plant would not only provide Armenia with adequate generation capacity to provide for energy independence, but it will also allow it to sell its surplus to its neighbors, such as Georgia, Iran, and other CIS countries. It may be wise for the EU or France to contribute to the funding of this project, as it will hasten the creation of a safer nuclear operation, and it will allow for return on investment with the EU through economic, energy, and diplomatic gains. Also, this project provides an opportunity to bolster relations between Armenia and Georgia by offsetting the dependence on Russian energy.

An additional consideration is the Trump administration's decision to pull the United States out of the JCPOA (Joint-Comprehensive Plan of Action) with Iran. ${ }^{50}$ In pulling out of the deal, the United States will be re-imposing strict sanctions on Iran ${ }^{51}$ and businesses of allied countries that conduct business with Iran, leaving Iran desperate for a regional economic partner. Armenia is positioned to take advantage of this opportunity, specifically with a new nuclear facility. Considering these strategic energy moves, Armenia may have the opportunity for financial and diplomatic gains and to strategically rebalance power relationships.

\section{Russia's Role}

Russian-Armenian relations have a long history, most notably beginning after the treaty of Turkmenchay, signed between Persia (Iran) and Russia in 1828, wherein it was agreed that Russia would occupy the territory dedicated to the hosted

47 Armen Manvelyan, "Energy Security in Armenia: Challenges and Opportunities," in The South Caucasus 2018: Facts, Trends, Future Scenarios (Tbilisi: Konrad Adenauer Stiftung, 2013), 127-128, 137.

48 "Nuclear Power in Armenia," World Nuclear Association, March 2018, www.worldnuclear.org/information-library/country-profiles/countries-a-f/armenia.aspx.

49 "Nuclear Power in Armenia."

50 Mark Landler, "Trump Abandons Iran Nuclear Deal He Long Scorned," The New York Times, May 8, 2018, https://nyti.ms/2KMeG2f.

51 "Executive Order Reimposing Certain Sanctions with Respect to Iran," The White House, August 6, 2018, https://www.whitehouse.gov/presidential-actions/executiveorder-reimposing-certain-sanctions-respect-iran/. 
Armenian population. ${ }^{52}$ From the perspective of many Armenians, the Russians saved the Armenians from the Turks following the Genocide by giving them security under the Soviet Union. ${ }^{53}$ Besides a brief moment of independence in 1917, Armenia became a sovereign state in 1991 after about 70 years of Soviet rule. ${ }^{54}$

While Russia is Armenia's energy and military security guarantor, primary trade partner and ally, Russia helps as much as it hinders Armenia. First, due to the Nagorno-Karabakh conflict with Azerbaijan, Armenia endures internal, regional, and international negative consequences as discussed previously. Although Russia is not involved in the conflict, it is the only power that can unilaterally end the conflict. However, without Russia and its security guarantees for Armenia the conflict cannot be solved either. Furthermore, it is not in Russia's interest to end the Nagorno-Karabakh conflict for a plurality of reasons - primarily because it allows Russia to maintain some control over the two former Soviet Republics through dependence (economic, military, and diplomatic) and, secondly, Russia has the opportunity for financial gain through arms sales to both Armenia and Azerbaijan.

Second, while Armenia strives to become energy independent, it is dependent on Russian state-owned companies that have nearly monopolized the energy sector of Armenia ${ }^{55}$; this includes the Metsamor nuclear facility, which is operated by a Russian subsidiary company. ${ }^{56}$ In addition, Armenia's strides to become energy independent through alternative sources like hydroelectric, solar, wind, or the building of a new nuclear facility are all hindered by lack of funding. ${ }^{57}$ Therefore, Russia provides funding to invest in these projects under the conditionality that Russian companies profit from them in return for the investment. ${ }^{58}$ Thus, in practice, Armenia still cannot become energy independent.

Third, because Armenia is dependent on Russian oil and gas, it joined the Eurasian Economic Union (EEU) in 2013 for further subsidized rates on its energy imports. ${ }^{59}$ There is also speculation that, in light of the EU's interest in Armenia,

52 "The Treaty of Turkmenchay between Russia and Iran Signed," Russian Federation Presidential Library, February 22, 1828, https://www.prlib.ru/en/history/619048.

53 Razmik Panossian, "Post-Soviet Armenia: Nationalism \& Its (Dis)contents," in After Independence: Making and Protecting the Nation in Postcolonial and Postcommunist States, ed. Lowell W. Barrington (Ann Arbor, MI: The University of Michigan Press, 2006), 226, https://www.press.umich.edu/pdf/0472098985-ch9.pdf.

54 Panossian, "Post-Soviet Armenia," 225-226.

55 Paul Stronski, "Armenia at Twenty-Five: A Rough Ride," Carnegie Endowment for International Peace, December 6, 2017, https://carnegieendowment.org/2016/12/ 07/armenia-at-twenty-five-rough-ride-pub-66351.

56 "Nuclear Power in Armenia."

57 "Nuclear Power in Armenia."

58 "Nuclear Power in Armenia."

59 Pasquale De Micco. "When Choosing Means Losing: The Eastern Partners, the EU, and the Eurasian Economic Union," European Parliament, March 2015, 20, http://greatereurope.org/archives/5742. 
Russia implicitly pressured Armenia to join the EEU in order to exercise greater control. ${ }^{60}$ Regardless of Armenia's success in negotiating deals with both the EU and the EEU, ${ }^{61}$ the EEU still restricts Armenia from other western trade deals that could assist in diversifying its partners.

Fourth, Armenia's economy is dependent on seasonal or permanent labor remittances from Russia. About $14 \%$ of Armenia's annual GDP is generated from these remittances, ${ }^{62}$ giving Russia further leverage over Armenian politics and economy.

Fifth, Armenia suffers from Western sanctions placed on Russia. Due to worsening relations between Russia and the West, more sanctions on Russia have been levied following Russia's interference in the U.S. elections and the attempted assassination of Sergei Skripal and his daughter in Salisbury, UK. The impact on Armenia is direct, because the sanctions specifically target Russian oligarchs who control the companies that dominate Armenia's economy, such as Gazprom and Rosneft. ${ }^{63,64}$

\section{Conclusion: Armenia's Options}

Although Armenia is at a geopolitical disadvantage in the region, it has some options to consider. First, Armenia must strive to find a solution to the NagornoKarabakh conflict; most preferably through the Minsk Group of the Organization for Security and Cooperation in Europe. If a settlement can be reached between Azerbaijan and Armenia, many of the consequential issues Armenia faces will disappear as relations begin to repair and borders and trade open up.

Second, Armenia can diversify and enhance its energy sector. It can start by seeking international funding for development of alternative energy sources (wind, solar, hydro). This will offset the dependency on Russian energy and give Armenia a greater surplus to sell on regional markets. In addition, it is pertinent that Armenia finance and construct a new operational nuclear facility by 2026 to ensure the country has enough energy. If Armenia can acquire finances from various international investors instead of solely Russia, that will allow Armenia to further reduce its dependence and debt with Russia.

60 "Armenia Joins Eurasia Union," Radio Azatutyun, Radio Free Europe/Radio Liberty, January 3, 2015, https://www.azatutyun.am/a/26774782.html.

61 Emil Danielyan, "EU Reveals Landmark Deal With Armenia," Radio Azatutyun, Radio Free Europe/Radio Liberty, October 16, 2017, www.azatutyun.am/a/28798353.html.

62 "Personal Remittances, received (\% of GDP)," The World Bank, 2018. https://data.worldbank.org/indicator/BX.TRF.PWKR.DT.GD.ZS?locations=AM.

63 "Sectoral Identifications List," Office of Foreign Assets Control, U.S. Department of Treasury, July 25, 2018, 4 and 51, https://www.treasury.gov/resource-center/ sanctions/SDN-List/Pages/ssi_list.aspx.

64 "Enforcement Information for July 20, 2017," Office of Foreign Assets Control, U.S. Department of Treasury, July 20, 2017, 1, https://www.treasury.gov/resourcecenter/sanctions/CivPen/Documents/20170720_exxonmobil.pdf. 
Third, considering the completion of the TANAP and the re-imposition of Iranian sanctions, development of the North-South Energy Corridor would be a wise option.

\section{Acknowledgements}

I gratefully acknowledge the PhD Pathways Program of New York University, Graduate School of Arts and Sciences, for the funding provided to this research initiative, as well as the Caucasus Research Resource Center - Armenia Foundation for the support and sponsorship of my efforts.

\section{About the Author}

Anthony R. Branch is a graduate student at New York University. During the summer of 2018 he lived in Yerevan, Armenia as an International Fellow for the Caucasus Research Resource Center - Armenia Foundation, wherein he conducted his research using both primary and secondary sources, interviewed local thought leaders and learned the Armenian language. His work has already featured in the Journal of Political Inquiry at New York University.

E-mail: arb744@nyu.edu. 


\section{Bibliography}

"Armenia Joins Eurasia Union," Radio Azatutyun, Radio Free Europe/Radio Liberty, January 3, 2015, https://www.azatutyun.am/a/26774782.html.

"Armenian Ceasefire Violation: Azerbaijan's Serviceman Killed," Trend, January 19, 2018, https://en.trend.az/azerbaijan/karabakh/2849943.html.

"Azerbaijan Has Bought SOM Missile from Turkey," Azeri Defence, June 26, 2018, http://en.azeridefence.com/azerbaijan-has-bought-som-missile-from-turkey.

"BP Statistical Review of World Energy," 67th Edition, BP, June 2018, www.bp.com/ content/dam/bp/en/corporate/pdf/energy-economics/statisticalreview/bp-stats-review-2018-full-report.pdf.

"Crude Oil Prices Down Sharply in Fourth Quarter of 2014," U.S. Energy Information Administration, January 6, 2015, https://www.eia.gov/todayinenergy/ detail.php?id=19451.

"Enforcement Information for July 20, 2017," Office of Foreign Assets Control, U.S. Department of Treasury, July 20, 2017, https://www.treasury.gov/ resource-center/sanctions/CivPen/Documents/20170720_exxonmobil.pdf.

"Executive Order Reimposing Certain Sanctions with Respect to Iran," The White House, August 6, 2018, https://www.whitehouse.gov/presidential-actions/ executive-order-reimposing-certain-sanctions-respect-iran/.

"Nagorno-Karabakh Conflict," Council on Foreign Relations, October 2017, https://www.cfr.org/interactives/global-conflict-tracker\#!/conflict/nagornokarabakh-conflict.

"Nagorno-Karabakh Reports 250 Azerbaijani Ceasefire Violations," Tert, March 3, 2018, http://www.tert.am/en/news/2018/03/03/karabakh/2629054.

"Nagorno-Karabakh's Gathering War Clouds," Europe Report no. 244. Brussels: International Crisis Group, June 1, 2017, available at https://d2071andvip0wj.cloudfront.net/244-nagorno-karabakhs-gatheringwar-clouds.pdf.

"Nuclear Power in Armenia," World Nuclear Association, March 2018, www.world-nuclear.org/information-library/country-profiles/countries-af/armenia.aspx.

"Personal Remittances, received (\% of GDP)," The World Bank, 2018, https://data.worldbank.org/indicator/BX.TRF.PWKR.DT.GD.ZS?locations=AM.

"Sectoral Identifications List," Office of Foreign Assets Control, U.S. Department of Treasury, 4 and 51, July 25, 2018, https://www.treasury.gov/resourcecenter/sanctions/SDN-List/Pages/ssi_list.aspx.

"The Treaty of Turkmenchay between Russia and Iran Signed," Russian Federation Presidential Library, February 22, 1828, https://www.prlib.ru/en/ history/619048. 
Altstadt, Audrey L., and Rajan Menon, "Unfrozen Conflict in Nagorno-Karabakh: Why Violence Persists," Foreign Affairs, April 12, 2016, www.foreignaffairs.com/ articles/armenia/2016-04-12/unfrozen-conflict-nagorno-karabakh.

Asatryan, Garnik S., "Armenia and Security Issues in the South Caucasus," Connections: The Quarterly Journal 1, no. 3 (2002): 21-30.

Danielyan, Emil, “EU Reveals Landmark Deal with Armenia," Radio Azatutyun, Radio Free Europe/Radio Liberty, October 16, 2017, www.azatutyun.am/ a/28798353.html.

De Micco, Pasquale, "When Choosing Means Losing: The Eastern Partners, the EU, and the Eurasian Economic Union," European Parliament, March 20, 2015, http://greater-europe.org/archives/5742.

De Waal, Thomas, "The South Caucasus in 2020," in Russia in 2020: Scenarios for the Future, ed. Maria Lipman and Nikolay Petrov, 109-122. Washington, D.C.: Carnegie Endowment for International Peace, 2011.

Geukjian, Ohannes, Negotiating Armenian-Azerbaijani Peace: Opportunities, Obstacles, Prospects. Burlington, VT: Ashgate, 2014.

Giragosian, Richard, "Shifting Security in the South Caucasus," Connections: The Quarterly Journal 6, no. 3 (Fall 2007): 100-106.

Gurbanov, Ilgar, "Interaction with Turkish Air Force Boosts Azerbaijan's AirCombat Capability," Eurasia Daily Monitor 14, no. 137 (The Jamestown Foundation, October 26, 2017), https://jamestown.org/program/ interaction-turkish-air-forces-boosts-azerbaijans-air-combat-capability/.

Harris, Gardiner, "U.S. To Issue New Sanctions on Russia Over Skripals' Poisoning," The New York Times, August 8, 2018, https://nyti.ms/20Uvbvo.

Hill, Fiona, Kemal Kirişci, and Andrew Moffatt, "Armenia and Turkey: From Normalization to Reconciliation," Brookings Institution, February 24, 2015, www.brookings.edu/articles/armenia-and-turkey-from-normalization-toreconciliation/.

Kaufman, Stuart J., Modern Hatreds: The Symbolic Politics of Ethnic War. Ithaca, NY: Cornell University Press, 2001.

Kocharyan, Hayk, "Regional Security Dynamics: Azerbaijan," Analytical Bulletin 76, Center for Civilization and Cultural Studies, 2017.

Kotanjian, Hayk, "Armenian Security and U.S. Foreign Policy in the South Caucasus," Connections: The Quarterly Journal 3, no. 2 (Summer 2004): 15-32.

Landler, Mark, "Trump Abandons Iran Nuclear Deal He Long Scorned," The New York Times, May 8, 2018, https://nyti.ms/2KMeG2f.

Larrabee, Stephen F., and Alireza Nader, "Central Asia and the Caucasus," in Turkish-Iranian Relations in a Changing Middle East, 19-20. Santa Monica, CA: RAND Corporation, 2013, www.rand.org/pubs/research_reports/ RR258.html. 
Lipman, Maria, and Nikolay Petrov, eds., Russia in 2020: Scenarios for the Future. Washington, D.C.: Carnegie Endowment for International Peace, 2011.

Lissner, Rebecca Friedman, and Mira Rapp-Hooper, "The Day after Trump: American Strategy for a New International Order," The Washington Quarterly 41, no. 1 (Spring 2018): 7-25.

Luhn, Alec, "Armenia Opposition Leader Nikol Pashinyan Elected PM by Parliament," The Telegraph, May 8, 2018, https://www.telegraph.co.uk/ news/2018/05/08/armenia-opposition-leader-nikol-pashinyan-elected-pmparliament/.

Manvelyan, Armen, "Energy Security in Armenia: Challenges and Opportunities," in The South Caucasus 2018: Facts, Trends, Future Scenarios, 127-141. Tbilisi: Konrad Adenauer Stiftung, 2013.

Manvelyan, Armen, Energy Security and Geopolitical Challenges in the CaucasusCaspian Region. Yerevan, Armenia: Yerevan State University, 2015.

Manvelyan, Armen, The Implications for Eurasian Economic Union and South Caucasus Energy Policy. Yerevan: Institute of Oriental Studies, National Academy of Science, April 2018.

Panossian, Razmik, "Post-Soviet Armenia: Nationalism \& Its (Dis)contents," in After Independence: Making and Protecting the Nation in Postcolonial and Postcommunist States, ed. Lowell W. Barrington, 225-247. Ann Arbor, MI: The University of Michigan Press, 2006., https://www.press.umich.edu/pdf/ 0472098985-ch9.pdf.

Shiriyev, Zaur, Eka Tkeshelashvili, and Mitat Celikpala, "Institutionalizing a Trilateral Strategic Partnership: Azerbaijan, Georgia, Turkey," Policy Paper, (Konrad Adenauer Stiftung, 2016), http://www.kas.de/wf/doc/kas_43884-15221-30.pdf.

Stronski, Paul, "Armenia at Twenty-Five: A Rough Ride," Carnegie Endowment for International Peace, December 6, 2017, https://carnegieendowment.org/ 2016/12/07/armenia-at-twenty-five-rough-ride-pub-66351.

Zhuchkova, Yulia, "Armenia's Hands Are Tied Regarding Russian Arms Sales to Azerbaijan," The Jamestown Foundation, July 26, 2017, available at https://jamestown.org/armenias-hands-are-tied-regarding-russian-armssales-to-azerbaijan/. 